\title{
散乱法と分子モデリングで見る糖鎖の溶液構造
}

\author{
Solution Structures of Polysaccharides in Aqueous Solutions
}

by Small Angel X-ray Scattering with Synchrotron Radiation and Molecular Modeling

浦川

1.はじめに

糖鎖は、たんぱく質と並ぶ代表的生体高分子である。糖 鎖の生理活性機能の重要性は認識されつつも、光の機能と 構造との相関を探る研究が注目され始めたのは比較的最近 である。たんぱく質の多くが結晶化できるほどのリジッド な高次構造を有し、乥の構造研究には単結晶 X 線構造解 析が有力な研究手段となる。現在も、単結晶 $X$ 線構造解 析法によるたんぱく質の三次元構造が、ポストゲノムのひ とつの研究テーマとして官民をあげて強力に推進されてい る。一方、糖鎖の構造は光れほどリジッドではなく、結晶 中における形態と機能発現時の構造が同等であるのかが問 われ、機能が発現する条件下での構造観察がたんぱく質に 比較してより強く要求されてきた。従って、たんぱく質の 構造と機能が、単結晶 X 線構造解析から得た原子座標を 用いて分子・原子の大きさのレベルで検討されるのに対し て、糖鎖の場合には、光の大きさのレベルでの重要な構造 情報を欠いて進められてきた。これまで、糖鎖の分子鎖形 態を論ずる場合、半屈曲性高分子としての取り扱いがほと んどであり、実験結果もこのモデルでよく説明できる。と ころが、糖鎖の特徵であるゲル化や生理活性機能は、糖鎖 の局所構造に由来すると考えられ、このような抽象的なモ デルでは構造と機能の相関を十分に検討することはできな い。

たんぱく質も同樣であるが、糖鎖の多くが水溶液中で機 能を発現する。この樣子を直接観察する方法としてはX 線、光、中性子線などの散乱法の利用が有効とされる。し かしながら、弚れらの結果から、分子・原子の大きさのレ ベルで構造を議論するには困難が伴う。散乱体の構造に関 する情報が、空間的及び時間的に平均化されているためで ある。乥のような平均化された情報を直接解析し、散乱体 の詳細な構造モデルへと導くことは非常に難しい。これを 克服する手段として、実空間で散乱体の構造モデルを構築、

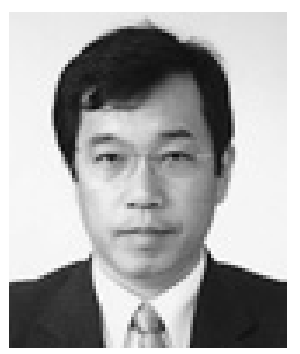

HIROSHI URAKAWA

京都工芸纎維大学 工芸学部 教授 工学博士

于 606-8585 京都市左京区松ヶ崎御所海 道町

Tel : 075-724-7567 Fax : 075-724-7564

E-mail : urakawa@chem.kit.ac.jp

〈専門〉高分子物性、染色化学

〈趣味〉家庭菜園、パソコンの自作と改 良
兴の散乱強度の角度依存性(散乱曲線)を計算、実測データ と比較検討することが行われてきだ。我々の研究グルー プは、近年目覚しい発展と充実を遂げつつあるモンテカル 口法、分子力学法、分子動力学法、分子軌道法など、いわ ゆる分子モデリングを構造モデル構築の手法として積極的 に取り入れてきた。シミュレーションした構造モデルを用 いて、散乱実験と比較検討する手法を検証し、糖鎖の分子 レベルでの構造の可視化を試みてきた。乥の結果を本稿で は解説したい。

2 . 放射光利用小角 $X$ 線散乱実験と分子モデリング

分子モデルから平均化された散乱曲線を計算することは、 決して目新しいことではない。散乱体を構成する原子の三 次元座標がわかれば、次の Debye の式を用いて計算でき る。

$$
I(q) \approx \sum_{i=1}^{n} g_{i}^{2} \phi_{i}^{2}(q)+2 \sum_{i=1}^{n-1} \sum_{j=i+1}^{n} g_{i} g_{j} \phi_{i}(q) \phi_{j}(q) \cdot \frac{\sin d_{i j} q}{d_{i j} q}
$$

ここで $g_{i}$ は原子散乱因子、 $d_{i j}$ は $\mathrm{i}$ 番目原子と $\mathrm{j}$ 番目原子 間の距離、

$\phi_{i}(q)$ は i 番目原子の形状因子である。原子がvan der Waals 半径 $R_{i}$ の剛体球であると仮定すれば、光の形状因 子は次式に従う。

$$
\phi_{i}(q)=\frac{3\left[\sin \left(R_{i} q\right)-\left(R_{i} q\right) \cos \left(R_{i} q\right)\right]}{\left(R_{i} q\right)^{3}}
$$

したがって、分子モデリングから提案される具体的構造を、 散乱曲線とすることは比較的容易である。では、なぜ積極 的に構造解析にこれまで用いられなかったのであろうか。 分子モデリングの手法が特殊なハードとソフトを手にした 者だけに限られたという理由だけではない。むしろ精度の 高い散乱実験の難しさに原因があったと考える。溶液から の散乱実験は、単結晶からの回折実験と比較して、測定で きる散乱強度は原理的に非常に小さい。さらに、目的とす る散乱体の構造解析は、散乱体が溶液中で孤立状態である こと、すなわち希薄溶液での測定を要求する。したがって、 詳細な解析に耐えられるだけの散乱曲線を実測することは 甚だ困難であった。これを克服する可能性が、電子蓄積リ ングから発生する放射光によって拓かれた。放射光から $X$ 線を取り出して小角 X 線散乱実験に用いようとする試み である ${ }^{2)}$ 。実験室系のX 線発生装置と比へて、光の輝度が 数桁高く、実測散乱曲線の $S / N$ 比の飛躍的な向上が見込 
めた。いまでは、数多くの構造研究が放射光利用小角 $X$ 線散乱実験で行われている。我々の研究手法が一応の成果 を収めつつあるのも、高エネルギー加速器研究機構物質構 造科学研究所放射光研究施設での放射光利用共同実験によ るところが大きい。実際、ほとんどの散乱実験を同施設で 行っている。小角 X 線散乱法は、約 100nm 程度までの大 きさの構造を観察する手段として有力とされるが、分子レ ベルの構造の差をどの程度まで捉えることができるかを検 討しておく必要がある。光こで、分子モデリングが比較的 容易である染料分子の会合体構造について検討した”。測 定した銅フタロシアニン系染料は、大きな平面構造をもち、 水溶液中で会合体として存在することが知られている。通 常の方法による実測散乱曲線の解析から、会合体は棒状で あり、低温になるほど会合度は増加し、棒の長さ方向に大 きくなることが認められた。この結果は、分子の平面が互 いに積み重なる会合樣式を強く示唆した。光こで、分子間 の距離と積み重ねの方向を構造パラメータとして会合体の 構造モデルを提案した(図 1の右図参照)。光の原子位置座 標から計算される散乱曲線と実測散乱曲線を比較すること で構造パラメータの決定を試みた。図 1 に $35^{\circ} \mathrm{C}$ における 結果をクラトキープロット $\left(q^{2} I(q) v s . q 、 I(q)\right.$ : 散乱強度、 $q$ : 散乱ベクトルの大きさ)で示す。パラメータが炎れぞ れ $8 \AA ̊$ と $25^{\circ}$ の時に、図 1 に示すような良好な一致を得た。

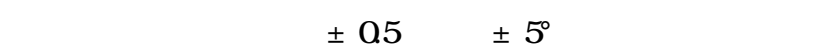
適モデルを提案できた。高温になると、分子間距離は広が り角度も大きくなり、会合体内で分子間のすべり運動が温 度とともに激しくなることが解った。これらの結果は、分 子モデリングを妥当な仮定の下で併用すると小角 $X$ 線散 乱実験データによっても散乱体を 3 次元分子モデルとして 可視化でき、詳細な構造解析が行えることを意味している。

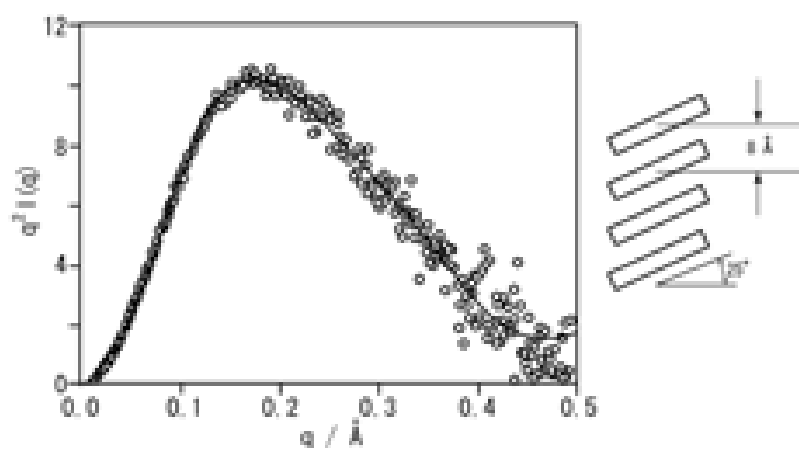

図 1 図 1 フタロシアニン系染料会合体の実測散乱強度 (○)と分子モデルから求めた計算散乱曲線(実線)の 比較。右図は、計算に用いた会合体モデル分子平面 に平行な方向から眺めた概略図。矩形が 1 分子に対 応する。

3. 糖鎖 (キシログルカン)の溶液およびゲルの構造 これまでに多くの糖鎖の構造解析を、上述した手法で 行ってきた ${ }^{4,5,6)}$ が、ここではモノマーからゲルまでの溶液

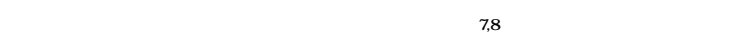

3.1 キシログルカン

キシログルカンは種子や細胞壁に存在する非澱粉植物多 糖の総称である。光の分子鎖構造は、主鎖である $(1 \rightarrow 4)$ -

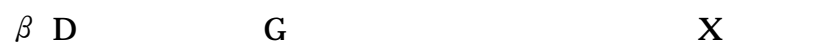
クトキシロース基 $(\mathrm{L})$ で構成される。繰り返し単位は、主 鎖に4つのグルコース残基をもち、含まれる側鎖の数と種 類の違いから図 2 の 4 種があるが、关の比率は植物種子に より異なる。これらは、アジア・アフリカ地域で食品や食 品添加剂(主として増粘剂)として広く利用されてきた。近 年では、光の生理活性に関する研究が進み、種子の種類で 異なる生理活性を示すことが明らかにされている。例えば、 デタリウム由来のキシログルカンは食後の血中グルコース やインシュリン濃度増加を抑える効果があるが、タマリン ド由来のものには关のような効果は報告されていない。ま たキシログルカンは、アミロース以外でヨウ素呈色を示す 多糖類として知られるが、デタリウムやタマリンド由来の ものは非常に強くヨウ素呈色を示すものの、アフェツェリ ア由来のものは弱く呈色する程度であり、ジャトバ由来の ものは全く呈色しない。このように、同じキシログルカン でも由来によって異なる生化学及び物理化学的特性を持つ。 ここで最も興味を引かれる点は、キシログルカンの一次構 造あるいは高次構造が光の生理活性と関連があるのか、あ るとすればどのように関連しているのか、を明らかにする ことにある。このためには、まずキシログルカンの希薄溶 液物性を詳細に理解する必要があろう。キシログルカンは
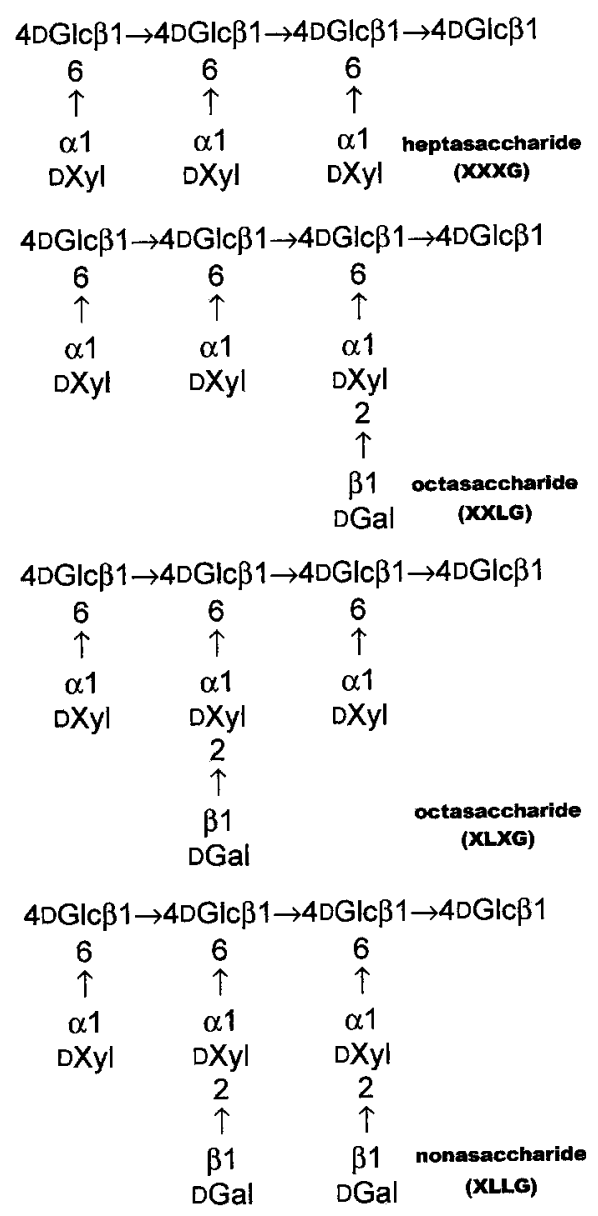

図 2 種のキシログルカンモノマーの構造 
親水性側鎖をもつために、溶液濃度を高めても粘度が上昇 するだけで、ゲル化することはないが、酵素による分解反 応で、側鎖を $50 \%$ 程度以上取り除くと室温でもゲル化す るようになる。このゲルは、温度を下げても、また温度を 上げてもゾルになる特徵をもつ。

\section{2 キシログルカンモノマーとオリゴマー}

キシログルカンを酵素分解し、分離精製すると図 2 の 4 種のモノマーが得られる。また、部分加水分解の条件を吟 味することで、光れらの $2,3,4$ 量体を調整することがで きる。これらの水溶液の小角 X 線散乱実験の結果を図 3 に示す。 7 糖と 9 糖からなるモノマーの水溶液から実測さ れた小角 $X$ 線散乱強度のクラトキープロットである。一 方、各モノマーを分子動力学法でモデリングしたところ図 3 に示すモデルが得られた。右側は骨格部分のみを取り出 したものである。これらの原子座標から計算した散乱関数 を図 3中の実線で示したが、実測散乱強度をよく再現する。 従って、シミュレーション結果は実際のモノマーの水中で の形態をよく反映していると考えられる。分子モデルを眺 めてみると、光の骨格はモノマーに依存せず、ピラノース リングを同一平面状に並べる、断面が扁平な形態をとる。 また、側鎖はそ看に対して平行に突き出て、側鎖のピ ラノースリングが主鎖のピラノースリングと直角になるよ うにねじれていることがわかる。

オリゴマーについての解析でも、モノマーと同樣に分子 鎖形態が扁平な断面をもつリボン状であること、断面の回 転半径がモノマーから 4 量体までほとんど変化しないこと からキシログルカン鎖の剛直性が確認できた。
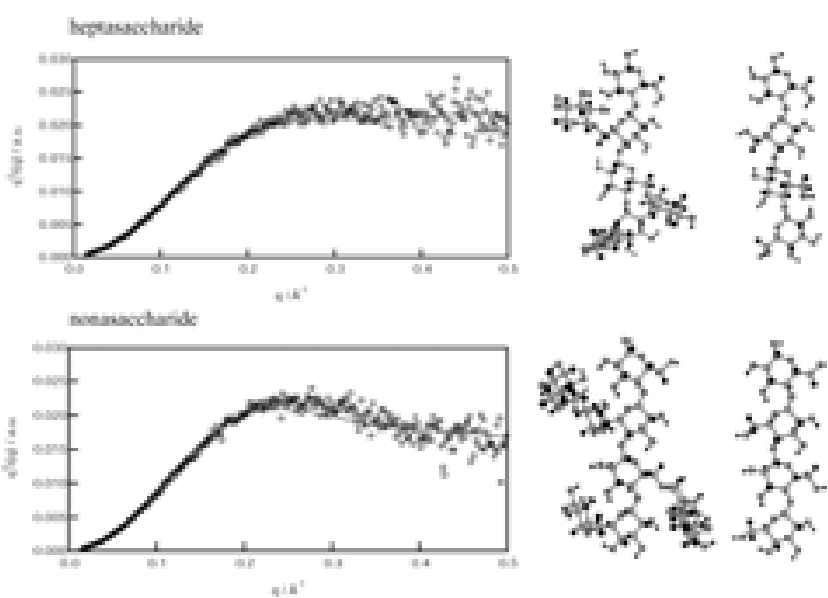

図 3 キシログルカンモノマーの実測散乱強度 $(\bigcirc)$ と分子 モデルから求めた計算散乱曲線(実線)の比較と分子 モデル。右の分子モデルは主鎖のみを表示。

\section{3 キシログルカンポリマー}

分子量が大きくなると、小角 $\mathrm{X}$ 線散乱法で分子鎖全体 の構造を捉えることはできない。光こで光散乱測定と組み 合わせた解析を試みた ${ }^{8)}$ 。動的・静的光散乱測定の結果、 キシログルカンは、全体としてガウス鎖として振舞い、局 所的には上述した岡直な棒状の構造をもつ。光こで、図 4

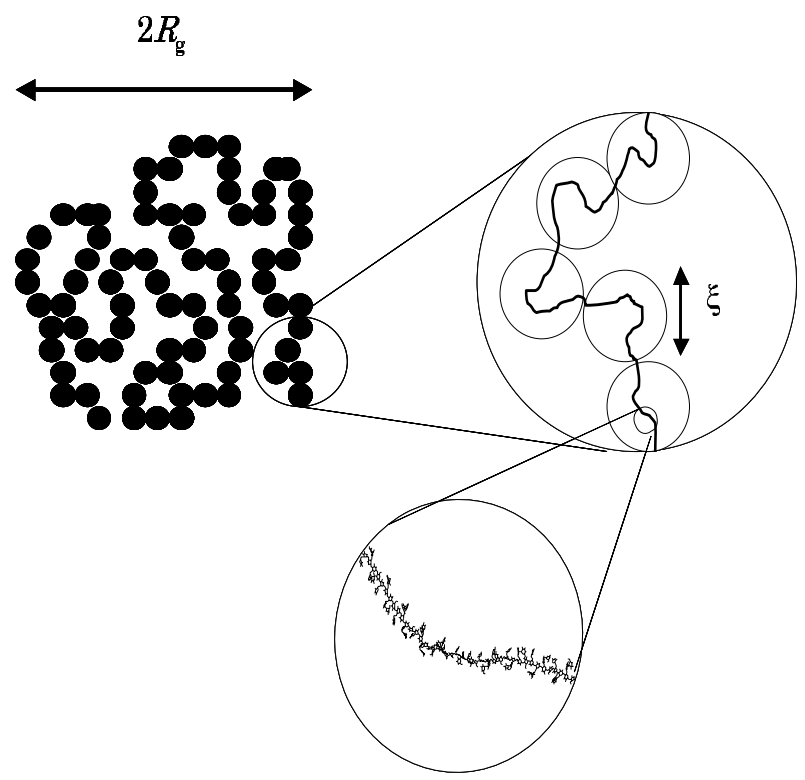

图 4 キシログルカンポリマーの構造モデル

のような構造モデルを考えた。すなわち、微視的な領域で は、剛直な構造をとり、 $\xi$ 程度の長さまでこの岡直性が持

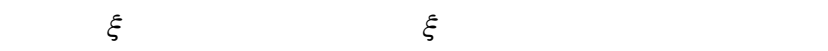
連結され、全体では回転半径 $R_{g}$ を持つガウス鎖として振 舞うとするモデルである。このモデルを数式化すると次式 となる。

$$
I(q)=A(q)^{2}\left[\frac{2}{x^{2}}(\exp (-x)-1+x)+\frac{c \xi^{2} q^{2}}{1+\xi^{2}+q^{2}}\right]
$$

ここで、 $x=R_{g}^{2} q^{2} 、 c$ は右辺第 2 項の重みを決める定数で ある。右辺は形状因子 $A(q)$ と構造因子の積の形であり、 $A(q)$ は形状因子で、1つのブロッブからの散乱振幅をあ らわす。ここでは、キシログルカン分子鎖をXXXG の繰 り返しでシミュレーションした分子モデルの散乱振幅を $A(q)$ とした。静的光散乱測定において濃度を 0 に外挿し た散乱曲線及び小角 $X$ 線散乱測定から得られた散乱曲線 の両方に対して同時に上式をフィッティングした。弚の結 果を図 5 に示す。明らかに、どの種子由来のキシログルカ

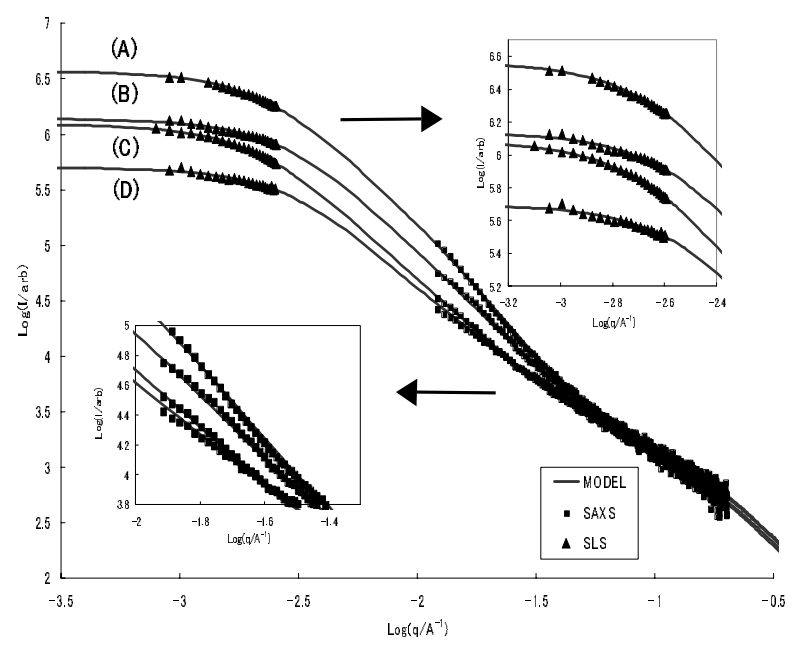

図 5 静的光散乱曲線と小角 X 線散乱曲線を用いた種々 のキシログルカン分子鎖形態の解析。A : アフェ ツェリア、B：デタリウム、C：ジャトバ、D：タ マリンド 
ンに対しても全領域で散乱現象が再現された。このことか ら、図 4のような構造がキシログルカンの分子鎖形態とな ることが示された。最適なフィッティングを与えたパラ メータで、注目すべきは $\xi$ の值である。アフェツェリア とジャトバが5.Onm, 9.0nm と小さいのに対して、タマリ ンドとデタリウムでは 15.0nm, 13.0nm となった。種子の 違いに起因する分子鎖形態の差が、剛直な性質が持続する 長さに現れたことになる。これが異なった生理活性を生み 出す一因ではないかと推測している。

\section{4 キシログルカン水溶液のゲル}

前述したように、キシログルカン水溶液は、ガラクトキ シロース側鎖の立体障害と親水性のためにゲル化しない。 ガラクトース残基を $50 \%$ 程度酵素分解反応で取り除けば 白濁したゲルを形成する。光こで、タマリンドキシログル カンが酵素分解していく過程を時分割小角 X 線散乱で観 察した。光の結果を図 7 にクラトキープロットの形で示す。 酵素反応が進むに従って中角部分で顕著な変化が現れてい る。ゲル化後の実測散乱曲線をギニエ近似により解析する と、厚み $1.1 \mathrm{~nm}$ の薄層会合体の形成が認められた。水溶 液中のキシログルカン分子鎖が剛直なリボン状の形態であ るとの結果と合わせて、リボンの平面を積み重ねるように 会合し、架橋ドメインを形成すると考え、架橋ドメインの 分子モデルを図 6 に示すように構築した。モデルの構築に 用いたキシログルカンは、 $(1 \rightarrow 4)-\beta-D$-グルカン 40 残基 からなる骨格をもち、30個の $(1 \rightarrow 6)-\alpha$-キシロースの分岐 をもつ。分岐側鎖の一部は $(1 \rightarrow 2)-\beta$-ガラクトキシロース で置き換えてある。このモデル鎖を規則的に 14 本並べて 平板状の架橋ドメインとした。このドメインの厚みは実測

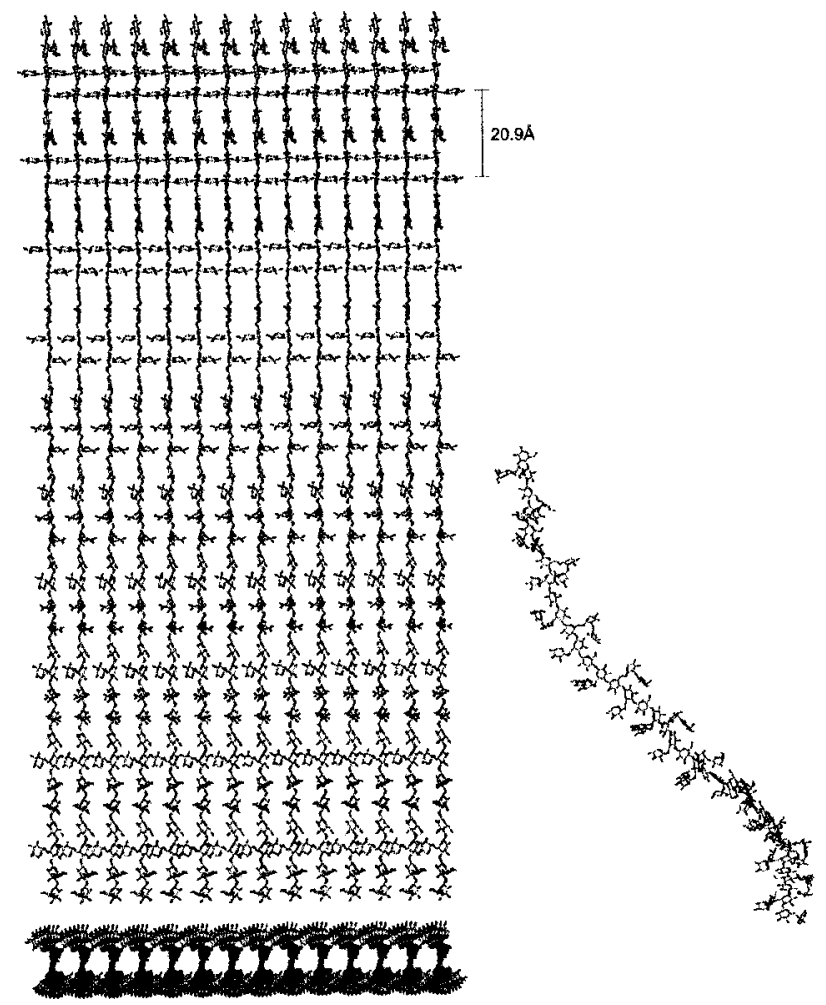

図 6 キシログルカンの架橋ドメインと孤立鎖の分子モデル

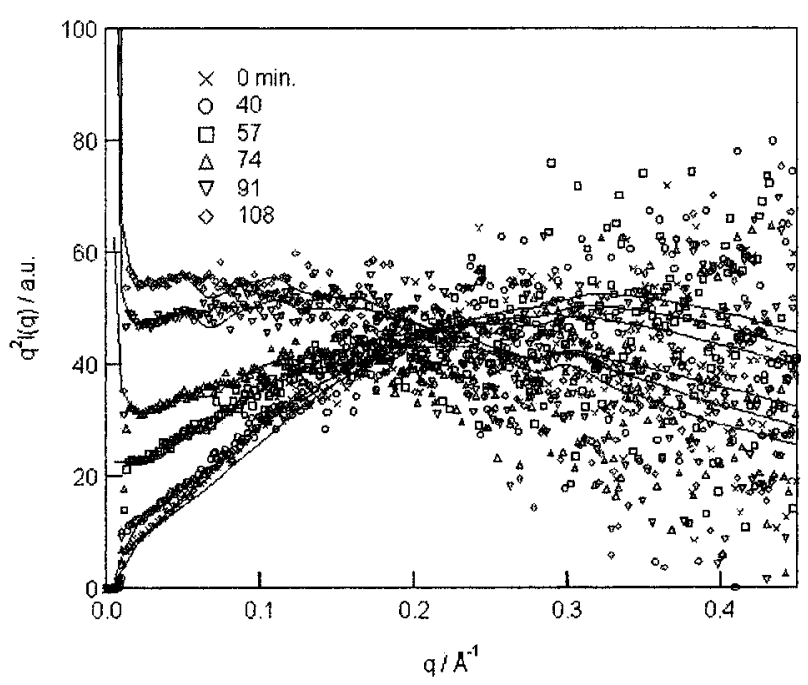

図 7 酵素分解の進行に伴うキシログルカン水溶液のゲル 化の小角 X 線散乱による観察。実線は構造モデル から計算される散乱曲線。

表 1 酵素分解時間に伴うゲル構造のパラメータの変化

\begin{tabular}{|c|c|c|c|c|}
\hline 反応時間 & \multirow{2}{*}{$(\mathrm{f}-1) \alpha$} & $\mathrm{b}$ & \multicolumn{2}{|c|}{ 重量分率 } \\
\cline { 4 - 5 } & & $(\mathrm{nm})$ & 孤立鎖 & 架橋ドメイン \\
\hline 0 & 0.45 & 6.0 & 1.0 & 0.00 \\
\hline 40 & 0.5 & 11.0 & 0.49 & 0.51 \\
\hline 57 & 1.0 & 13.5 & 0.24 & 0.76 \\
\hline 74 & 1.04 & 13.7 & 0.13 & 0.87 \\
\hline 91 & 1.06 & 14.0 & 0.07 & 0.93 \\
\hline 108 & 1.07 & 14.0 & 0.05 & 0.95 \\
\hline
\end{tabular}

散乱曲線の解析から見積もられた值とほぼ同じである。1 本鎖のシミュレーションは、同じモデル鎖を分子動力学計 算することで行った(図 6右)。

一方、ゲル構造からの散乱曲線を計算するために、ゲル 化が古典的なフローリー・ストックマイヤーの多官能重縮 合スキームに従い、樹木状に成長するとした。このゲル化 のモデルから散乱強度は

$$
\begin{aligned}
& I(q)=A(q)^{2}(1+\alpha \phi) /[1-(f-1) \alpha \phi] \\
& \phi=\exp \left(-b^{2} q^{2} / 6\right)
\end{aligned}
$$

で計算される9)。f(架橋ドメインの官能基数(ここではド メインからの分岐数)、(は反応度、 $\mathrm{b}^{2}$ (は隣り合う単位間 の平均二乗距離、 $A^{2}(q)$ は各散乱単位の散乱振幅である。 散乱単位が有限サイズのドメインで構成される場合、 $A^{2}(q)$ は钅のドメインの散乱因子で与えられる。したがって、こ こでは、キシログルカンの会合体と孤立鎖の散乱因子から なることになる。会合が進むと、ドメインが多官能性基と して機能し、樹木が生長し、ゲル化に至るモデルである。 作成したキシログルカンのモデルから散乱因子を計算し、 このゲル化モデルに基づき、実測小角 X 線散乱曲線を解 析した。結果は、図 7 中の実線で示すが、計算散乱曲線と 実測散乱強度は、反応全過程でほぼ良好な一致を示す。解

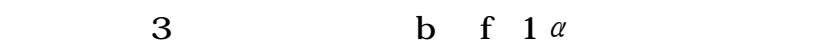
橋ドメインの重量分率)の值を表 1 にまとめておく。酵素 分解が進行するに従い、より多くの架橋ドメインが形成さ 
れ、平均分岐度が増すことがわかる。ゲル化点 $((\mathrm{f}-1) \alpha=$ 1)においては、約 $75 \%$ の鎖が、108分後ではほとんどの 鎖が架橋ドメイン形成に関与している。散乱単位間距離 b は反応時間と共に増加するが、ゲル化後はほぼ一定值とな る。架橋ドメインの分子モデルからわかるように、会合し た鎖は平板な形をした濃厚相を形成している。正確に 14 本の鎖が並列しているとは言えないが、厚みが 1.1nmで あることから、架橋ドメインはキシログルカン鎖一層で、 細胞状の網目を構成する薄い壁になると考えられる。

$$
\text { 4.まとめ }
$$

これまで、溶液構造を散乱実験で検討しても、分子の大 きさのレベルでの解析は困難とされてきた。しかしながら 上で述べたように、散乱体の構造に関する情報を十分に収 集し、分子モデリングに活用すれば、三次元分子モデルと して構造を可視化しながら、散乱実験の結果を検討できる 可能性が十分にあることがわかった。糖鎖水溶液の構造解 析において、光の有用性を示すことができ、糖鎖の機能と 構造の相関に関する研究を進める一つの方向として期待で きる。

文献

1) 例えば、O.Glatter and O.Kratky (eds) ,Academic Press,
London(1982).

2) 例えば、野島修一、新高分子実験学 6 高分子の構造 (2)」2.3放射光 $X$ 線解析、共立出版 (1994).

3) H. Santo, M. Shimode, H. Urakawa and K. Kajiwara, Proceedings of "ATC '97 (The 4th Asian Textile Conference)" , T aiwan, 787(1997).

4) B. T. Stokke, K. I. Draget, O. Smidsr $\phi$ d, Y. Yuguchi, H. Urakawa and K. Kajiwara, Macromolecules, 33, 1853 (2001).

5) M. Dentini, P. Desideri, V. Crescenzi, Y. Yuguchi, H. Urakawa and K. Kajiwara, Macromolecules, 34, 1449 (2001).

6) T. T. T. Thanh, Y. Yuguchi, M. Mimura, H. Yasunaga, R. Takano, H. Urakawa and K. Kajiwara, Macromol. Chem. Phys., 203, 15(2002).

7) H. Urakawa, M. Mimura and K. Kajiwara, Trends in Glycoscience and Glycotechnology, 14, 355(2002).

8) 家入大輔、河村幸伸、安永秀計、湯口宜明、浦川 宏、 梶原莞爾、纎維学会誌、59, 93(2003).

9) H. Urakawa, Y. Ikeda, Y. Yuguchi, K. Kajiwara, Y. Hirata and S. Kohjiya, Polymer Gels and Networks, O sada and Khokhlov(eds), Marcel Dekker 1(2001).

\title{
第 17 回複合材料セミナー \\ -- 先端産業から地球環境まで - 産業用途を中心に発展する炭素䋐維
}

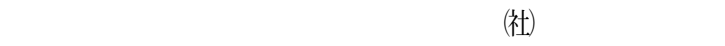 \\ 日 時: 平成 16年 3月 2 日(火) 10:00～17:00(セミナー) $17: 15$ 19: 15(懇親会) \\ 会 場 : 東京大学「山上会館」東京都文京区本郷 7-3-1 TEL : 03-3818-3008 \\ 〔交通〕地下鉄：丸の内線「本郷 3丁目」、千代田線「根津」、南北線「東大前」下車 \\ 都バス：東大構内行き(学 01)「上野松坂屋前から」「東大病院前」下車 \\ プログラム、参加申込の詳細は、下記にお問い合せ下さい。 \\ 干 104-0061 東京都中央区銀座 2-11-8 第 22 中央ビル (社)強化プラスチック協会内 炭素㵶維協会 \\ 複合材料セミナー事務局 TEL : 03-3543-1531 FAX : 03-3543-1536
}

\section{第 1 回キンカ高分子化学研修コース \\ 高分子化学の実学を身につけさせたい上司、身につけたい新人に朗報}

\author{
主 催 : 近畿化学協会 協 賛 : (社)繊維学会ほか \\ 日 時: 平成 16 年 3 月 22 日(月) $9: 30 \sim 18: 30$ \\ 会 場 : 大阪科学技術センター8階中ホール [大阪市西区勒本町 1-8-4] \\ プログラム、参加申込の詳細は、下記にお問い合せ下さい。 \\ 干 550-0004 大阪市西区鞄本町 1-8-4 社団法人近畿化学協会高分子化学研修コース係 \\ TEL : 06-6441-5531 FAX : 06-6443-6685 E-mail : mail@kinka.or.jp
}

